Article

\title{
Compounds from Viburnum sargentii Koehne and Evaluation of Their Cytotoxic Effects on Human Cancer Cell Lines
}

\author{
Ki-Eun Bae, Han-Soo Chong, Dong-Sup Kim, Young-Woong Choi, Young-Sook Kim and \\ Young-Kyoon Kim *
}

Department of Forest Products and Biotechnology, College of Forest Sciences, Kookmin University, Seoul, 136-702, Korea; E-Mail: kieun@kookmin.ac.kr (K.B.)

* Author to whom correspondence should be addressed; E-Mail: ykkim@kookmin.ac.kr;

Tel.: +82-63-910-5092; Fax: +82-63-910-4809.

Received: 2 April 2010; in revised form: 14 May 2010 / Accepted: 9 June 2010 /

Published: 25 June 2010

\begin{abstract}
Compounds were isolated from a methanol extract of the dried stem barks of Viburnum sargentii Koehne. The structures of the compounds, namely 9'-O-methylvibsanol (3), furcatoside A (4) and lareciresinol (5) were elucidated by analysis of spectroscopic data and comparison with values for previously known analogues. In addition, (+)-catechin (1), (+)-epicatechin (2) were also isolated. This work also examined the cytotoxic effects of three compounds 3-5 (25-100 $\mu \mathrm{M})$ in MCF-7 and A549 cells after 24, 48 and $72 \mathrm{~h}$ of exposure. Our results showed that 9'-O-methylvibsanol (3) exhibited strong concentration-dependent anticancer effects according to the MTT assay and produced morphological changes consistent with apoptosis, as confirmed by Ho3342 staining analysis revealed that more apoptotic cells were observed after 9'-Omethylvibsanol (3) treatment.
\end{abstract}

Keywords: Viburnum sargentii; Caprifoliaceae; furcatoside A; 9'-O-methylvibsanol; lareciresinol; Cancer cells; antitumor activity

\section{Introduction}

Cancer is the second leading cause of death worldwide after cardiovascular diseases. Despite many therapeutic advances, mortality is still unacceptably high [1]. Most of the drugs used today in the clinic were first discovered from plants and microorganisms [2], therefore natural products are increasing 
interest and importance to cancer patients. In addition, these therapeutic agents have been reported to exert their antitumor effects by inducing apoptosis. Apoptosis, or programmed cell death, is an essential event that plays an important role in organism development and homeostasis. Apoptosis is a tightly regulated process characterized by cell shrinkage, plasma membrane blebbing, and chromatin condensation that is consistent with DNA cleavage in ladders [3,4]. Therefore, the induction of apoptotic cell death is an important mechanism in the anticancer properties of many drugs. During the course of screening plant materials possessing cell disordering activities toward cancer cells, the extract of $V$. sargentii Koehne was identified. The Viburnum genus (Caprifoliacea) comprises more than 200 species, shrubs or trees, mainly distributed in Southern America and in Asia and very abundant in the Chinese spontaneous flora [5]. Viburnum species are commonly used in folk medicine for their diuretic, antispasmodic and sedative properties, mainly for uterine excitability [6]. The genus Viburnum is known to be rich in iridoid glycosides, characterized by a sugar moiety at C-11 and an isovaleroyl group at C-1 (Valeriana-type iridoids) that have been isolated from several Viburnum species [7-10,14,21]. In addition, the known phytochemical studies carried out on Caprifoliaceae species have revealed triterpenoids [11], phenolic compounds [12] and benzofuran-type lignans [13]. Phytochemical studies on $V$. sargenti have documented the occurrence of Valeriana-type iridoid glucosides: 7,10,2'-triacetylsuspensolide F, 1, and viburnoside IV and V [14].

The detection of marked cytotoxicity effects against several cancer cell lines including A549 (human lung adenocarcinoma), MCF-7 (human breast adenocarcinoma) in the methanolic extract of $V$. sargentii prompted us to further investigate the constituents of this plant. To our knowledge, no report has been issued on the anticancer effects of $V$. sargentii extracts, therefore, this plant was selected for the current study, aimed at the systematic separation, structural elucidation and biological evaluation of the secondary metabolites responsible for the observed activity.

\section{Results and Discussion}

The $\mathrm{MeOH}$ extract of the stem bark of $V$. sargentii was subjected to solvent-solvent partitioning, to yield hexane, dichloromethane, ethyl acetate and water soluble phases. The ethyl acetate extract exhibited cytotoxic activity on MCF-7, A549 cells. Fractionation of this extract by vacuum liquid chromatography resulted in two main fractions, $E_{1} \sim E_{2}$. The main constituent of active fraction $E_{1}$ was subjected to multiple chromatographic purifications, that afforded compounds 1 and 2 which were proved to be (+)-catechin (1), (+)-ephicatechin (2), respectively, and have already been evaluated and been found to possess antiinflammation, anticancer and diabetes properties. $E_{2}$ fraction was subjected to multiple chromatographic purifications, and afforded compounds 3,4 and 5 which were proven to be 9'-O-methylvibsanol (3), furcatoside A (4) and Lariciresinol (5) through ${ }^{1} \mathrm{H},{ }^{13} \mathrm{C}$ and mass spectral data respectively (Figure 1). 9'-O-methylvibsanol (3), furcatoside A (4), Lariciresinol (5) had been previously isolated from Viburnum awabuki [13], Viburnum furcatum [10], Wikstroemia elliptica [22] respectively. Lariciresinol (5) were reported to exhibit antioxidant, cytotoxic effects in MCF-7 cells [22,23], but no previous biological studies appear to have been performed on 9'-O-methylvibsanol (3).

Compound 3 had the molecular formula $\mathrm{C}_{20} \mathrm{H}_{20} \mathrm{O}_{6}$, suggesting the addition of an extra methyl group to vibsanol. The above similarity and difference suggest that 9'-O-methylvibsanol (3) should be also a benzofuran-type lignan having an extra methoxy group on C-9 or C-9' in vibsanol. Methoxy signal at 
$\delta_{\mathrm{H}} 3.46$ showed correlation with an isolated osymethylene $\left(\mathrm{C}-9^{\prime}\right)$ at $\delta_{\mathrm{C}} 64.5$. Thereby, the methoxy group was placed at the C-9' position, and the structure of compound 3 was elucidated as 9'-Omethylvibsanol (3). 9'-O-methylvibsanol (3) had been previously isolated from Viburnum awabuki [13].

Compound 4 have the 8',10',11'-oxygen substituted iridoid skeleton with an iso-valeroyl group at $\mathrm{C}-1$. The aromatic protons of a $p$-coumaroyl group showed two trans-olefinic proton resonances at $\delta_{\mathrm{H}}$ 6.4 and $7.7(1 \mathrm{H}$ each, $d, J=15.9 \mathrm{~Hz}$ ). The spectroscopic evidence led to its identification as furcatoside A that had been previously isolated from Viburnum furcatum [10]. Lariciresinol (5), similarly identified by spectroscopic analysis and comparison with literature data, had previously isolated from Wikstroemia elliptica [22].

Figure 1. Compound structures from Viburnum sargentii Koehne.

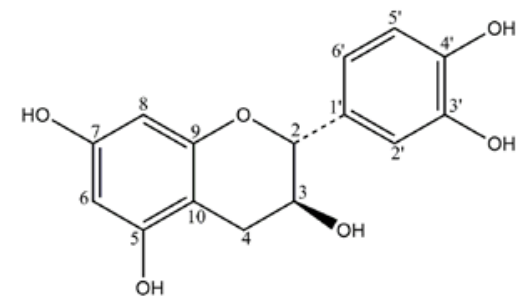

(+)-Catechin

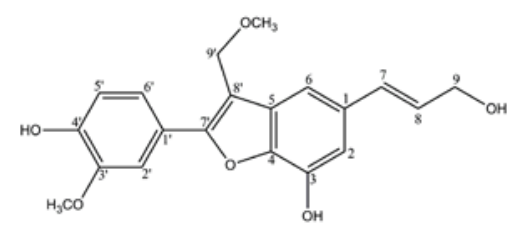

9'-O-methylvibsanol

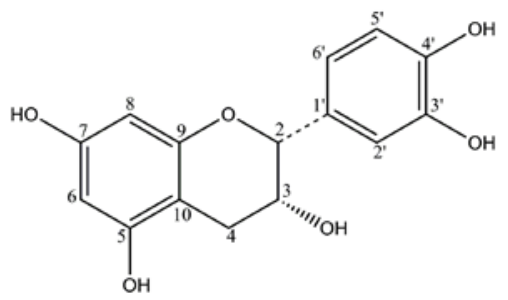

(+)-Epicatechin

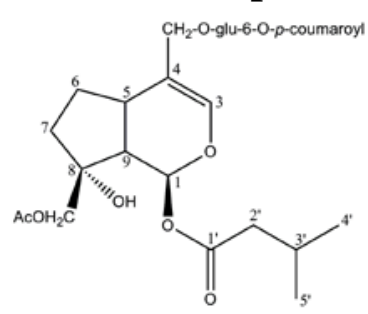

Furcatoside A

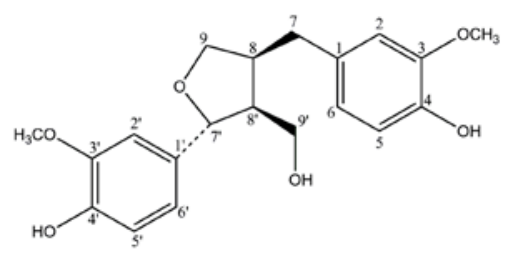

Lariciresinol

The effect of compounds 3, 4 and 5 on the cytotoxicity of MCF-7, A549 cells was examined first. Cells were treated with various concentrations of compound 3, 4, $5(25-150 \mu \mathrm{M})$ for indicated time periods (24, 48 and $72 \mathrm{~h}$ ) and cell cytotoxicity was then assessed using the MTT colorimetric assay [15].

As shown in Figure 2, treatment of MCF-7, A549 cells with compounds 3-5 resulted in a marked dose-dependent cytotoxicity. The $\mathrm{IC}_{50}$ values of compounds 3-5 showed that compound 3 showed the most significant cytotoxicity against MCF-7 cells (Table 1).

Since, compound 3 had strong inhibitory effects on MCF-7 and A549 cells growth, the appearance of morphological changes for the cells were observed in the concentration ranges from 25 to $100 \mu \mathrm{M}$ for 24, 48 and $72 \mathrm{~h}$ exposures for further mechanistic studies. Doxorubicin $(1 \mu \mathrm{M})$ and paclitaxel (25 $\mathrm{nM}$ ) were used as positive controls. In the next experiment, direct observation using a phase contrast microscope revealed that numerous morphological changes occurred in cells treated with 9'-Omethylvibsanol (3). Figure 3 shows these morphological changes of cells after: a) 24 h, b) 48 h and c) 72 h. After incubation with 9'-O-methylvibsanol (3), the cellular morphology of (A) MCF-7, (B) A549 cells was severely distorted and cells became round in shape. Also, the cells showed a reduction in cell volume, destabilization of the plasma membrane, indicating an increasing progression toward cell death in a dose-dependent manner. The untreated cells displayed normal, healthy shape with a distinct cytoskeleton. 
Figure 2. Cytotoxic effects of Compound 3-5 on MCF-7, A549 cell lines.

Furcatoside $A_{-}$MCF-7

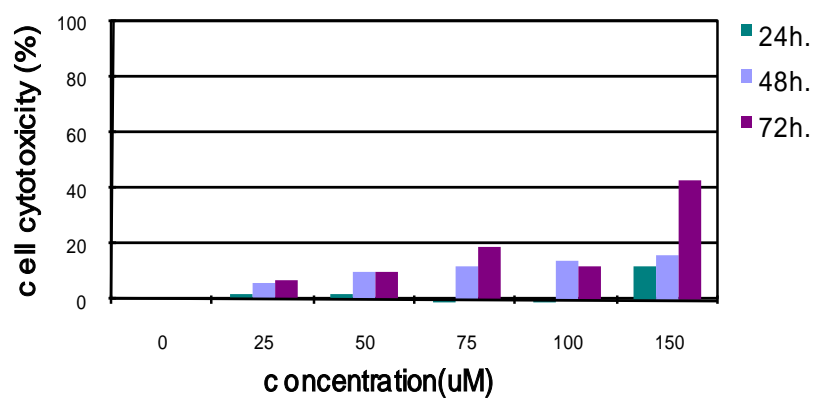

9'- O-methylvibsanol_MCF-7

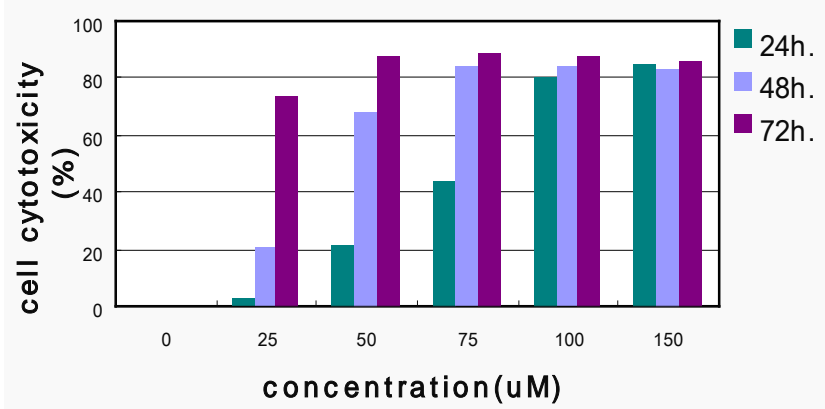

Lariciresinol_ MCF- 7

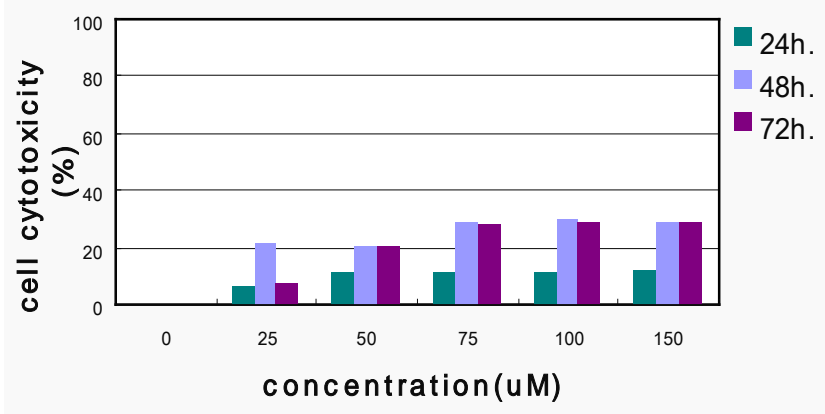

Furcatoside A_A549
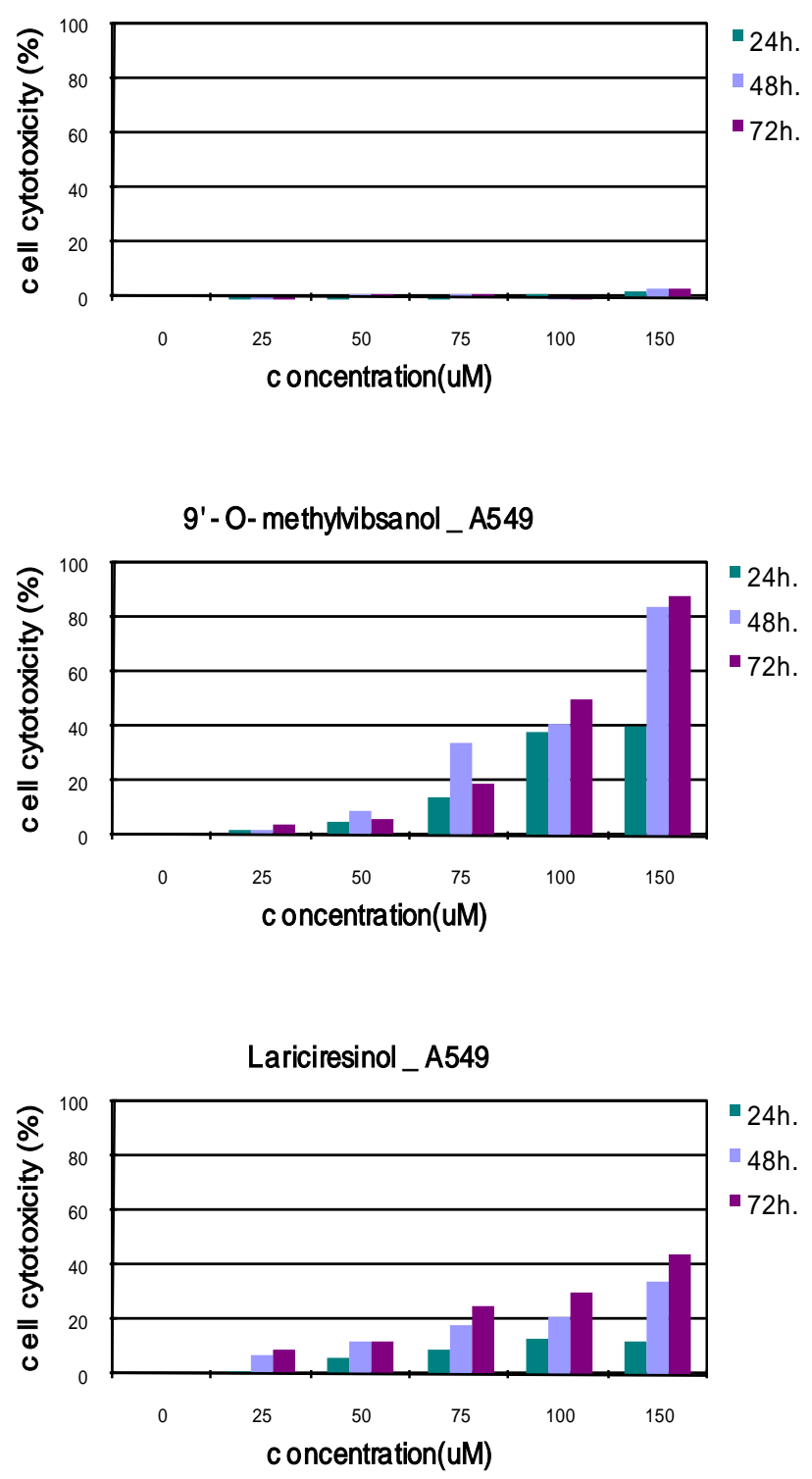

Table 1. Cytotoxic effects of compounds in tumor cell lines. $\mathrm{IC}_{50}(\mu \mathrm{M})$.

\begin{tabular}{|c|c|c|c|c|c|c|}
\hline \multirow{2}{*}{ substance } & \multicolumn{3}{|c|}{ MCF-7 } & \multicolumn{3}{|c|}{ A549 } \\
\cline { 2 - 7 } & $24 \mathrm{~h}$ & $48 \mathrm{~h}$ & $72 \mathrm{~h}$ & $24 \mathrm{~h}$ & $48 \mathrm{~h}$ & 103.0 \\
\hline 9'-O-methylvibsanol & 83.2 & 43.2 & 29.3 & 175.6 & 104.7 & \\
\hline Furcatoside A & 432.9 & 233.3 & 180.0 & & & 168.8 \\
\hline Lariciresinol & 686.1 & 259.6 & 281.4 & 539.1 & 225.3 & 6.9 \\
\hline Doxorubicin & 39.6 & 18.3 & 11.4 & 16.3 & 9.7 & 0.09 \\
\hline Paclitaxel & 0.062 & 0.060 & 0.055 & 0.36 & 0.11 & 0.09 \\
\hline
\end{tabular}


Figure 3. 9'-O-methylvibsanol (3) induced apoptosis in MCF-7, A549 cells. Morphological change of (A)MCF-7, (B)A549 cells observed under an inverted phase contrast microscope $(400 \times)$.

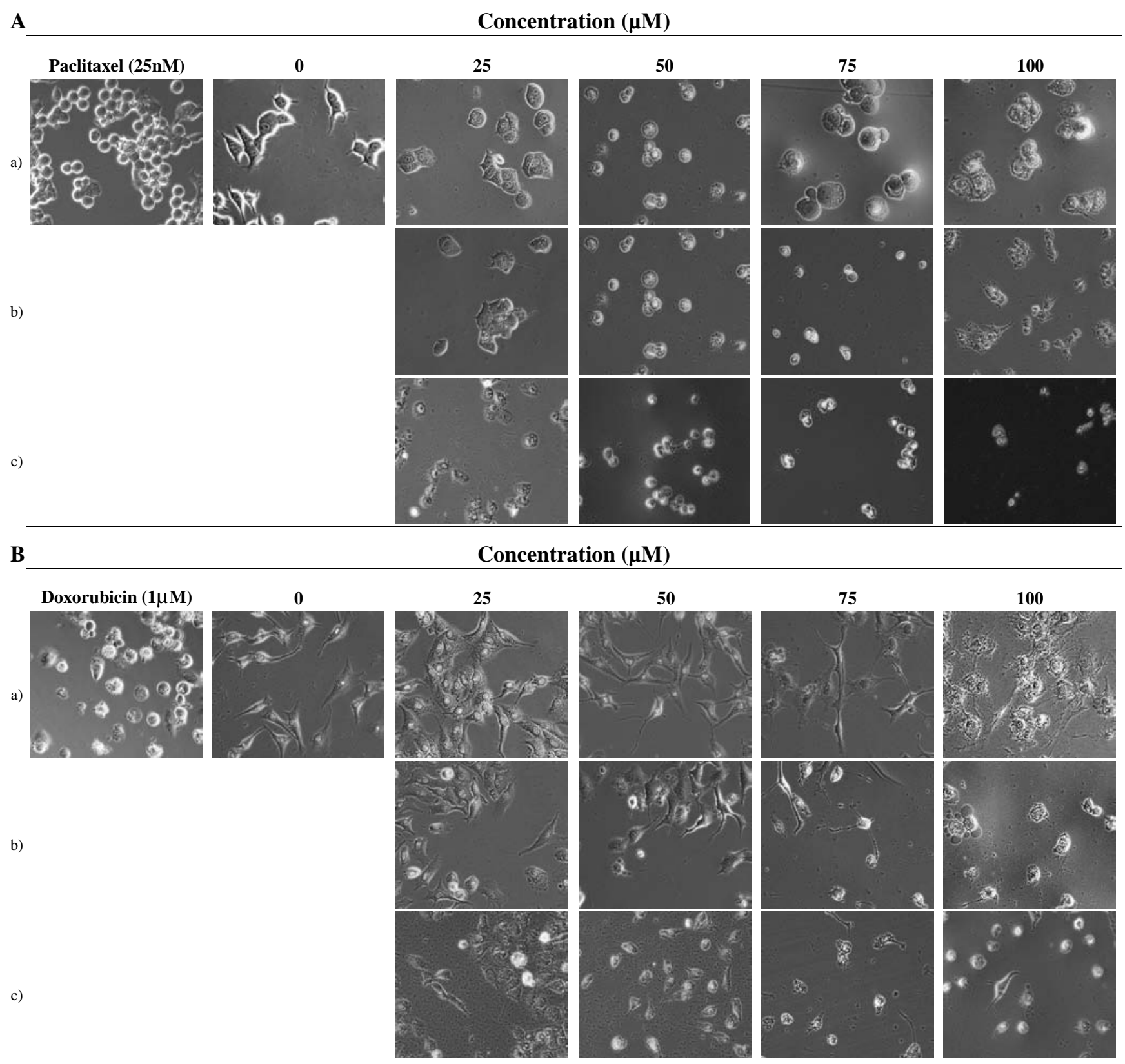

To elucidate whether 9'-O-methylvibsanol (3) inhibits the proliferation of MCF-7, A549 cells by inducing apoptosis, cells treated with compound $\mathbf{3}$ were examined after Ho33342 staining. The nuclei changes in MCF-7 cells were also observed under a fluorescent microscope $(200 \times)$. 
Figure 4. 9'-O-methylvibsanol (3) treated MCF-7 cells were stained by Ho33342. Nuclei morphologic changes observed by fluorescent microscopy (200 ×). (A) MCF-7, (B) A549 cells, respectively.

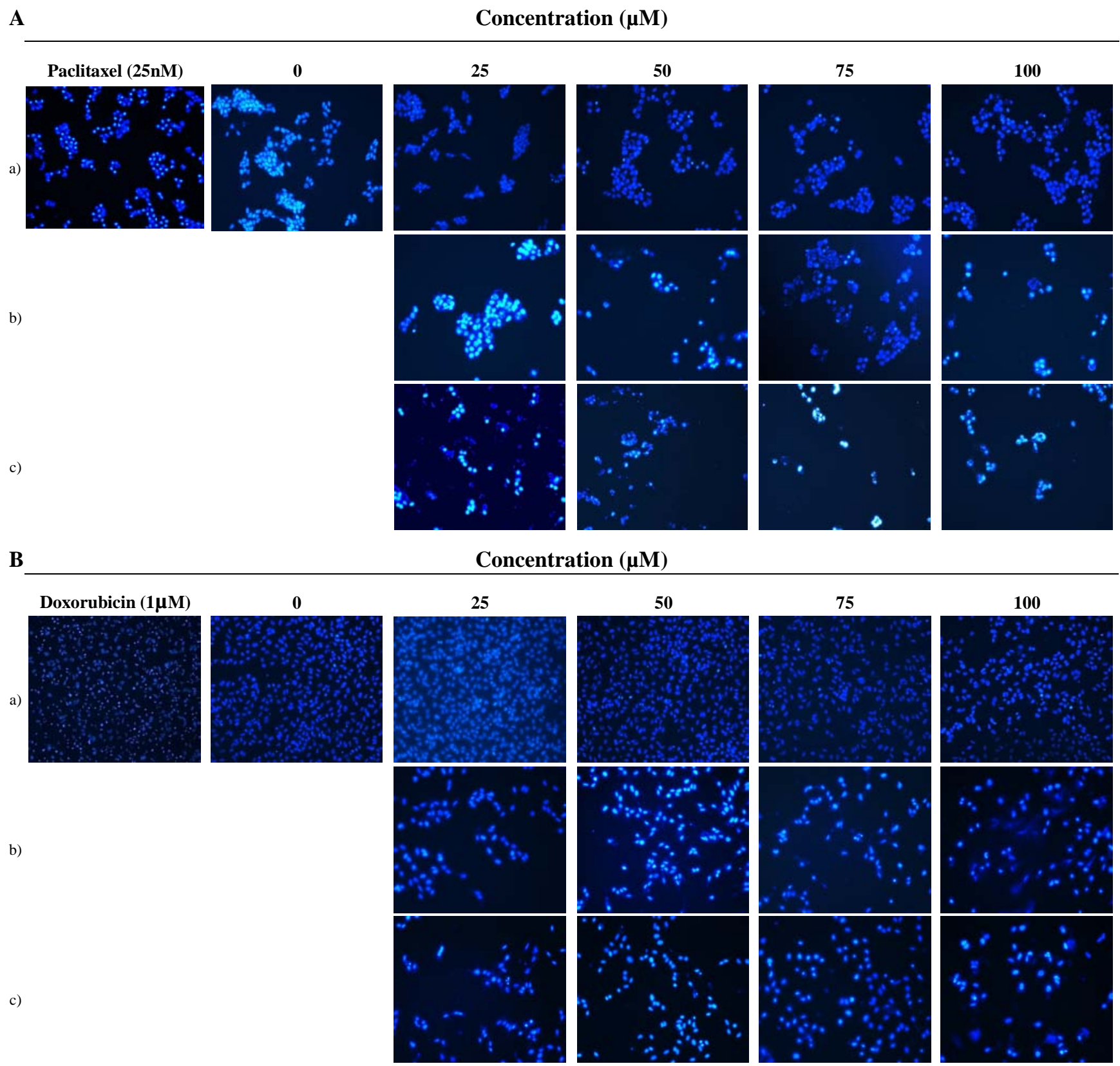

As shown in Figure 4, control cells emitted a blue fluorescence with consistent intensity, indicating that the chromatin was equivalently distributed in the nuclei. Following incubation with 9'-O-methylvibsanol for a) $24 \mathrm{~h}$, b) $48 \mathrm{~h}$ and c) $72 \mathrm{~h}$, the fluorescence light was denser and brighter compared to untreated control cell. Also, the cells showed chromatin condensation and karyopyknosis, which were typical apoptotic phenomena. Also cells showed typical apoptotic phenomena with chromatin condensation and karyopyknosis. Paclitaxel (25 $\mathrm{nM})$ and Doxorubicin $(1 \mu \mathrm{M})$ were used as positive control, (A) MCF-7, (B) A549 cells, respectively. 


\section{Experimental}

\subsection{Extraction}

The stem bark of $V$. sargentii was collected in Kyung dong market, Korea, in May 2008. One of the authors identified the plant, and a voucher specimen(YK07081) has been deposited at kookmin university, Korea. Dried stem bark of $V$. sargentii $(6.37 \mathrm{~kg})$ was extracted with $\mathrm{MeOH}(8 \mathrm{~L})$ three times at $46{ }^{\circ} \mathrm{C}$. The extracts were filtered and evaporated to dryness under vacuum to afford a brown gum (515.15 g) that was partitioned between dichloromethane and water and then the water layer was re-extracted with ethyl acetate. The two organic phases were evaporated to obtain dichloromethane (115.52 g) and ethyl acetate (121.10 g) extracts spots of which were monitored by thin layer chromatography eluting with $n$-hexane-EtOAc system. The spots were visualized by heating silica gel plates sprayed with $15 \% \mathrm{H}_{2} \mathrm{SO}_{4}$ in ethanol.

\subsection{Isolation}

The ethyl acetate fraction (41.3 g) was subjected to vacuum column chromatography on silica gel (400 mesh) column, eluting with a gradient of $n$-hexane-EtOAc (5:1 0:1), to yield two subfractions $E_{1} \sim E_{2}$. Subfraction $E_{1}(24.7 \mathrm{~g})$ was further separated by normal-phase silica gel (230 300 mesh) column chromatography, eluting with dichloromethane-MeOH (12:1), to yield subfractions $\mathrm{E}_{1}-1 \sim \mathrm{E}_{1}-2$. Subfraction $E_{1}-2$ (1.94 g) was purified by reverse-phase silica gel column chromatography, eluting with $\mathrm{MeOH}$-water (1:5), to afford compound 1 (140 mg) and compound 2 (100 mg). E 2 (2.57 g) was further separated by normal-phase silica gel column chromatography, eluting with dichloromethane$\mathrm{MeOH}$ (20:1), to afford subfractions $E_{2}-1 \sim E_{2}-5$. Subfraction $E_{2}-1$ was separated by normal-phase silica gel column chromatography, eluting with hexane-ethyl acetate (1:2) to yield compound 5 (10 mg). Subfraction $E_{2}-3$ was further separated by normal-phase silica gel (230 300 mesh) column chromatography, eluting with dichloromethane-MeOH (25:1), to yield compound 3 (20 mg). $\mathrm{E}_{2}-5$ was further purified by reverse-phase silica gel column chromatography, eluting with MeOH-water (1:1.2), to isolate compound 4 (50 mg). The structures of compounds were elucidated on the basis of UNITINOVA 300MHz NMR and mass spectral analysis with Micromass ZQ detector (Waters, Milford Massachusetts, USA). The chemical shifts are given in $\delta$ (ppm) and coupling constants in Hz.

9'-O-methylvibsanol (3). $\mathrm{C}_{20} \mathrm{H}_{20} \mathrm{O}_{6},\left(300 \mathrm{MHz}, \mathrm{CD}_{3} \mathrm{OD}\right) 6.87(1 \mathrm{H}, \mathrm{d}, J=1.5 \mathrm{~Hz}), 7.16(1 \mathrm{H}, \mathrm{d}$, $J=1.2 \mathrm{~Hz}), 6.63(1 \mathrm{H}, \mathrm{d}, J=15.6 \mathrm{~Hz}), 6.30(1 \mathrm{H}, \mathrm{d}, J=15.6,6 \mathrm{~Hz}), 4.24(2 \mathrm{H}, \mathrm{d}, J=6 \mathrm{~Hz}), 7.46(1 \mathrm{H}, \mathrm{d}$, $J=1.8 \mathrm{~Hz}), 6.89(1 \mathrm{H}, \mathrm{d}, J=8.4 \mathrm{~Hz}), 7.32(1 \mathrm{H}, \mathrm{dd}, J=8.4 \mathrm{~Hz}, 1.8), 4.62(2 \mathrm{H}, \mathrm{s}), 3.93$ (3H, s), 3.46 (3H, s); 133.5 (C-1), 108.3 (C-2), 142.2 (C-3), 142.2 (C-4), 132.2 (C-5), 108.8 ((C-6), 131.3 (C-7), 127.3 (C-8), 62.7 (C-9), 122.0 (C-1'), 110.5 (C-2'), 147.9 (C-3'), 147.7 (C-4'), 115.3 (C-5'), 120.6 (C$\left.6^{\prime}\right), 155.5\left(\mathrm{C}-7^{\prime}\right), 111.2\left(\mathrm{C}-8^{\prime}\right), 64.5\left(\mathrm{C}-9^{\prime}\right), 55.2\left(3^{\prime}-\mathrm{OCH}_{3}\right), 57.1\left(9^{\prime}-\mathrm{OCH}_{3}\right)$. ESI-MS (negative ion mode): m/z $649.104[\mathrm{M}-\mathrm{H}]^{-}$.

Furcatoside A (4). $\mathrm{C}_{32} \mathrm{H}_{42} \mathrm{O}_{14}$, (300MHz CD $\mathrm{CDD}_{3} \mathrm{O} 6.0$ (1H, d, $\left.J=6 \mathrm{~Hz}\right) .6 .62$ (1H, bs), 2.01(3H, s), 2.2 (2H, d, $J=6.6 \mathrm{~Hz}), 0.95$ (3H, d, $J=6.6 \mathrm{~Hz}), 3.3-4.8(6 \mathrm{H}), 6.4 / 7.7(1 \mathrm{H}, \mathrm{d}, J=15.9 \mathrm{~Hz}), 7.5(3 \mathrm{H}, \mathrm{d}$, 
$J=8.4$ Hz); 91.5 (C-1), 140.7 (C-3), 115.3 (C-4), 36.4 (C-5), 28.7 (C-6), 38.0 (C-7), 80.7 (C-8), 4.67 (C-9), 71.6 (C-10), 70.0 (C-11), 172.8 (COO), 20.8 (COOC $\left.\mathrm{CH}_{3}\right), 173.1\left(\mathrm{C}-1^{\prime}\right), 44.3\left(\mathrm{C}-2^{\prime}\right), 26.8$ (C-3'), 22.7 (C-4'), 22.7 (C-5'), $101.9\left(\mathrm{C}-1^{\prime \prime}\right), 71.3$ (C-2"), 75.3 (C-3"), 71.8 (C-4"), 78.1 (C-5"), 62.7 (C-6"),

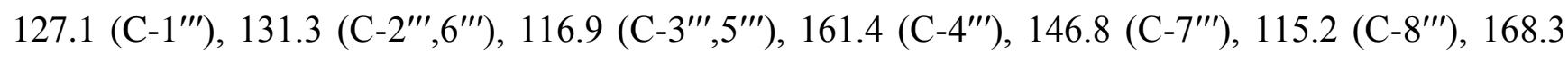
(C-9"'), ESI-MS (negative ion mode): m/z 355.04 [M-H]'.

Lariciresinol (5): $\mathrm{C}_{20} \mathrm{H}_{24} \mathrm{O}_{6}$, (300MHz CD $\mathrm{CD}_{3} \mathrm{OD} 2.42$ (1H, s), 2.54 (1H, dd, $\left.J=13.2 \mathrm{~Hz}, 10.9\right), 2.72$ (1H, s), 2.95 (1H, dd, $J=13.2 \mathrm{~Hz}, 4.8 \mathrm{~Hz}$ ), 3.77 (2H, s), 3.88 (3H, s), 3.90 (3H, s), 3.93 (1H, s), 3.99 $(1 \mathrm{H}, \mathrm{dd}, J=8.4 \mathrm{~Hz}, 6.3 \mathrm{~Hz}), 4.75(1 \mathrm{H}, \mathrm{d}, J=7.2 \mathrm{~Hz}), 4.99(1 \mathrm{H}, \mathrm{s}), 6.62-6.86(6 \mathrm{H}$, aromatic H); 132.3 (C-1), 112.0 (C-2), 146.5 (C-3), 144.6 (C-4), 114.3 (C-5), 121.0 (C-6), 32.5 (C-7), 42.7 (C-8), 72.3 (C9), 134.5 (C-1') 108.6 (C-2'), 146.8 (C-3'), 145.9 (C-4'), 114.0 (C-5'), 118.6 (C-6'), 82.8 (C-7'), 52.5 (C-8'), 59.2 (C-9'), 55.1 (3, 3'-OCH ${ }_{3}$ ), ESI-MS (negative ion mode): m/z 358.85 [M-H]'.

\subsection{Cell culture and drug treatment}

Human cancer cell line, A549 (human lung adenocarcinoma), MCF-7 (human breast adenocarcinoma), used in this work was purchased from the Korean Cell Line Bank (KCLB). A549, MCF-7 cells were cultured in Dulbecco's modified eagle medium (DMEM) supplemented with 10\% (v/v) fetal bovine serum (FBS), $100 \mathrm{U} / \mathrm{ml}$ penicillin, and $100 \mu \mathrm{g} / \mathrm{mL}$ streptomycin, in a humidified incubator containing $5 \% \mathrm{CO}_{2}$ at $37{ }^{\circ} \mathrm{C}$. Compounds isolated from $V$. sargentii were dissolved in dimethyl sulfoxide (DMSO) and the final DMSO concentration in all cultures was $0.5 \%$.

\subsection{Cell cytotoxicity assay}

The 3-(4,5-dimethylthiazol-2-yl)-2,5-diphenyltetrazolium bromide (MTT) assay is a common assay for cell cytotoxicity [15]. Briefly, growing cells were seeded at $1 \times 10^{5}$ cells/well in 96 well plates. After incubation for $24 \mathrm{~h}$. at $37{ }^{\circ} \mathrm{C}$, cells were exposed to various concentrations of 9'-Omethylvibsanol (3), furcatoside A (4) and Lariciresinol (5) and incubated for 12-72 h. Doxorubicin (1$10 \mu \mathrm{M}$ ), Paclitaxel (25 nM-1 $\mu \mathrm{M}$ ) were used as positive controls; negative control groups used same amount of DMSO. After incubation, the medium was removed and cells in each well were incubated with PBS contained $5 \mathrm{mg} / \mathrm{mL}$ MTT for $4 \mathrm{~h}$. at $37{ }^{\circ} \mathrm{C}$ in $5 \% \mathrm{CO}_{2}$ incubator. MTT solution was then discarded and $100 \mu \mathrm{L}$ of DMSO was added into each well to dissolve insoluble formazan crystals. Plates were then kept agitation for $30 \mathrm{~min}$ at room temperature for complete solubilization. The level of colored formazan derivative was analysed on a ELISA reader (Opsys $\mathrm{MR}^{\mathrm{TM}}$, Dynex) at a wavelength of $570 \mathrm{~nm}$. Results were expressed as the mean percentage of cell growth inhibition. The $\mathrm{IC}_{50}$ value was expressed as the concentration of compounds that inhibited the growth of cells by $50 \%$. (Figure 2). 


\subsection{Determination of morphological changes of cells}

\subsubsection{Observation of cells by phase contrast microscope}

Cells (5 × $10^{4}$ cells/well) were incubated for $24 \mathrm{~h}$ in 12 well plates. After incubation, the cells were untreated or treated with 9'-O-methylvibsanol (3) of four different concentrations for 24-72 h. Then the medium was removed and cells in wells were washed once with PBS. They were observed by phase contrast inverted microscope (Nikon, Japan) at $400 \times$ magnification (Figure 3). Doxorubicin $(1 \mu \mathrm{M})$ and Paclitaxel $(25 \mathrm{nM})$ were used as positive control for the A549 and MCF-7 cells, respectively.

\subsubsection{Benzimidazole Ho33342 staining}

Benzimidazole Ho33342 staining of MCF-7, A549 cells was performed to evaluate the cell death pattern induced by increasing concentrations of 9'-O-methylvibsanol (3). After 12, 24 and 72 h of incubation, cells were washed with PBS and fixed with methanol for $10 \mathrm{~min}$ at room temperature. Fixed cells were washed with PBS, and stained with $1 \mathrm{ug} / \mathrm{mL}$ benzimidazole Ho33342 solution for 30 min at incubation. The cells were washed twice more with PBS and analyzed with a fluorescence microscope (Figure 4). Doxorubicin $(1 \mu \mathrm{M})$ and Paclitaxel (25 nM) were used as positive control, A549 and MCF-7 cells, respectively.

\section{Conclusions}

Recently, a number of studies have demonstrated that apoptosis is of significant importance in the cytotoxic mechanism of chemotherapeutic agents in tumor cells. Apoptosis is a fundamental form of cell death which also plays a role in the development and homeostasis of multicellular organisms. During the course of screening plant materials possessing cell cytotoxic effects toward cancer cell lines, the extract of $V$. sargentii Koehne was selected in this experiment. We have isolated five compounds from stem bark of $V$. sargentii. Among these compounds, 9'-O-methylvibsanol (3) showed highly cytotoxicity of MCF-7, A549 cells with the lowest $\mathrm{IC}_{50}$ range (83.2 to $\left.29.3 \mu \mathrm{M}\right)$. Furthermore, the antitumor effects 9'-O-methylvibsanol (3) on MCF-7, A549 cells has not been reported previously. Consequently, we examined whether the apoptotic pathway is involved in the cell death caused by 9'O-methylvibsanol (3) in MCF-7, A549 cells. Firstly, we found that the MCF-7, A549 cells treated with 9'-O-methylvibsanol (3) acquired apoptotic morphological features such as becoming round in shape, reduction in cell volume, destabilization of the plasma membrane, indicating an increasing progression toward cell death in a dose-dependent manner (Figure 3). To elucidate whether 9'-O-methylvibsanol (3) inhibits the proliferation of MCF-7, A549 cells by inducing apoptosis, cells treated with compound were examined after Ho33342 staining. Results showed that MCF-7, A549 cells treated with 9'-O-methylvibsanol (3) displayed typical apoptotic phenomena with chromatin condensation and karyopyknosis (Figure 4). These results indicated that compound 3 induces apoptosis of MCF-7, A549 cells. These results may provide a basis for the potential therapeutic application of 9'-O-methylvibsanol and its related compounds to cancer therapy. 
However, further studies are needed to determine the mechanism of apoptosis pathway. In general, depending on the cell, apoptosis can be initiated in two ways: by extrinsic pathway or by an intrinsic pathway. In the former, plasma membrane death receptors are involved and the apoptosis signal is provided by interaction between the ligand and the death receptor, which then activates caspase- 8 and apoptotic cell death [16,17]. However, intrinsic pathway is triggered by the permeabilization of mitochondrial membranes, furthermore by releasing cytochrome c and ATP levels [18]. Cytochrome c and other apoptotic factors lead to the activation of caspase 9, which finally activates pro-caspase 3 to caspase-3. The activated caspases cleave cellular proteins and via caspase activated DNase (CAD) also chromatin $[19,20]$. Therefore, in-dept studies are needed to identify the apoptotic pathway of 9'-O-methylvibsanol (3) for its development as a cancer chemopreventive and/or anticarcinogenic agents.

\section{Acknowledgements}

This study was carried out with the support of Forest science \& Technology projects (project No. S210707L010110 and S120808L1101104) provided by Korea Forest Service and a 2008 Kookmin University research grant.

\section{References and Notes}

1. Reddy, L.; Odhav, B.; Bhoola, K.D. Natural products for cancer prevention: a global perspective Pharmacol. Ther. 2003, 99, 1-13.

2. Mann, J. Natural products in cancer chemotherapy: past, present and future. Nat. Rev. Cancer 2002, 2, 143-148.

3. Guy, M.; John, A.H. Apoptosis and cancer chemotherapy. Cell Tissue Res. 2000, 301, 143-152.

4. Ghobrial, I.M.; Witzig, T.E.; Adjei, A.A. Targeting apoptosis pathways in cancer therapy. $C A$ Cancer J. Clin. 2005, 55, 178-194.

5. Melchior, M. Engler's Syllabus der Pflanzenfamilien, 12th ed.; Nabu Press: Berlin, Germany, 1964; p. 474.

6. British Herbal Medicine Association. British Gerbil Pharmacopoeia; Scientific Committee: Bournemouth, UK, 1983; p. 230-232.

7. Boros, A.C.; Stermitz, F.R. Iridoids. An updated review, Part I. J. Nat. Prod. 1990, 53, 1055-1147.

8. Boros, A.C.; Stermitz, F.R. Iridoids. An updated review, Part II. J. Nat. Prod. 1991, 54, 1173-1246.

9. Fukuyama, Y.; Minoshima, Y.; Kishimoto, Y.; Chen, I.-S.; Takahashi, H.; Esumi, T. Iridoid Glucosides and p-Coumaroyl Iridoids from Viburnum luzonicum and Their Cytotoxicity. J. Nat. Prod. 2004, 67, 1833-1838.

10. Hase, T.; Iwagawa, T.; Dave, M.N. Three Iridoid glycosides from Viburnum furcatum. Phytochemistry 1985, 24, 1323-1327.

11. Shen, Y.-S.; Prakash, C.V.S.; Wang, L.-T.; Chien, C.-T.; Hung, M.-C. New Vibsane Diterpenes and Lupane Triterpenes from Viburnum odoratissimum. J. Nat. Prod. 2002, 65, 1052-1055. 
12. Tu, L.; Xu, G.; Zhao, Y.; Peng, L.-Y.; He, J.; Guo, N.; Zhao, Q.-S. Seven New Phenolic Glucosides from Viburnum cylindricum. Helvet. Chim. Acta 2009, 92, 1324-1332.

13. Fukuyama, Y.; Nakahara, M.; Minami, H.; Kodama, M. Two new benzofuran-type lignans from the wood of Viburnum awabuki. Chem. Pharm. Bull. 1996, 44, 1418-1420.

14. Tomassini, L.; Gao, J.; Serafini, M.; Nicoletti, M. Iridoid glucosides from Viburnum sargenti. Nat. Prod. Res. 2005, 19, 667-671.

15. Mosmann, T. Rapid colorimetric assay for cellular growth and survival: application to proliferation and cytotoxicity assay. J. Immunol. Methods 1983, 65, 55-63.

16. Jin, Z.; EI-Deiry, W.S. Overview of cell death signaling pathways. Cancer Biol. Ther. 2005, 4, 139-163.

17. Fulda, S.; Debatin, K.M. Extrinsic versus intrinsic apoptosis pathways in anticancer chemotherapy. Oncogene 2006, 25, 4798-4811.

18. Krammer, H. CD95(APO-1/Fas)-mediated apoptosis: live and let die. Adv. Immunol. 1999, 71, 163-210.

19. Zamzami, N.; Kroemer, G. The mitochondrion in apoptosis: how Pandora's box opens. Nat. Rev. Mol. Cell Biol. 2001, 2, 67-71.

20. Shigekazu, N. Apoptotic DNA Fragmentation. Exp. Cell Res. 2000, 256, 12-18.

21 Iwagawa, T.; Hase, T. An iridoid acetylalloside from viburnum japonicum. Phytochemstry 1986, 25, 1227-1229.

22 Dhang, Y.D.; Dharles, H.; Phoebe, J. Plant anticancer agents, XLII. Cytotoxic constituents from Wikstroemia elliptica. J. Nat. Prod. 1986, 49, 706-709.

23 Youngwon, C.; Heebyung, C. Lignan and other constituents of the fruits of Euterpe oleracea (Acai) with antioxidant and cytoprotective activities. J. Agric. Food Chem. 2008, 56, 7759-7764.

Sample Availability: Samples of the compounds are available from the authors.

(C) 2010 by the authors; licensee MDPI, Basel, Switzerland. This article is an Open Access article distributed under the terms and conditions of the Creative Commons Attribution license (http://creativecommons.org/licenses/by/3.0/). 